\title{
Teaching Design for Experiential Flipped Classroom Based on Ketangpai
}

\author{
Qing Qing \\ Lingnan Institute of Technology \\ Guangzhou, China 510663
}

\begin{abstract}
This paper introduces the free teaching management platform Ketangpai and experiential teaching method into the flipped classroom teaching mode, aiming at improving the enthusiasm of students and teachers and enhancing the efficiency and effectiveness of flipped classroom.
\end{abstract}

Keywords-classroom; experience; flip classroom

\section{INTRODUCTION}

It has been questioned that higher vocational college adopts the teaching mode of flipped classroom. The root of the question can be summarized into two aspects: the student and the teacher. Firstly, flipped classroom requires students to preview before class. Do higher vocational students have such high enthusiasm for learning? Secondly, flipped classroom requires the teacher to answer questions on the spot. In the case that each student makes very serious preview and has questions, the teacher only has dozens of minutes to answer the students' questions in class. Is the class time enough? In the flipped classroom, how to attract the attention of all students and improve students' understanding of difficult points? Since there is no teaching information platform in school, will it increase the amount of work to identify students' difficulties in the flipped classroom teaching mode?

In response to the above questions, this study introduces a free teaching platform Ketangpai, to effectively mobilize students' enthusiasm for learning and quickly identify the students' difficult points by using the powerful information dissemination, monitoring of learning processes, statistical analysis of learning behavior data, real-time interaction, and analysis of teaching quality of Ketangpai, so as to reduce the teacher's workload of identifying difficulties and preparing lessons. In addition, experiential teaching methods are used to attract the attention of all students and enhance their understanding of difficult points.

\section{KeTANGPAI}

Ketangpai is a free online classroom management platform that can provide teachers and students with convenient class management, online job correction, summary and analysis of performance, courseware sharing, and online discussion. Management courses include assignments, materials, announcements, tests, quick release, easy review, and efficient management.
Flipped classroom is inseparable from the aid of information technology. For teachers who do not have a teaching management platform, they can use Ketangpai to assist in flipped classroom teaching to improve teaching efficiency. At the same time, students only need to follow the WeChat official account of Ketangpai to participate in the topic interaction, so as to attract students' attention and improve students' learning efficiency.

\section{THE MEANING OF EXPERIENTIAL TEACHING}

\section{A. Concept of Experiential Teaching}

Experiential teaching is an interactive teaching form that refers to the method that starting from teaching needs, introduce, create or establish specific scenes or atmospheres that are appropriate to the teaching content to arouse the students' emotions experience, help students quickly and correctly understand the content of teaching and promote their comprehensive and harmonious development of mental function, in order to achieve the established teaching objective. Experiential teaching is not based on the teacher's unilateral knowledge infusion, but students need to perceive, understand and apply knowledge to form the corresponding skills or abilities through the actual feelings.

\section{B. The Characteristics of Experiential Teaching}

1) Active learning: Experiential learning emphasizes the active participation of learners. It is believed that without such participation, no experience can be produced, letting alone the completion of the learning process.

2) Teaching with joy: Teaching with joy is not the pleasure made by teachers unilaterally, but the fun that students actively experience. Students' learning happily is the real realization and real effect of teaching with "joy".

3) Applying the knowledge: Applying the knowledge is a difficult problem in traditional education. One of the reasons is that students rarely have the place, time and opportunity to apply knowledge to solve practical problems.

\section{SPECIFIC IDEAS OF EXPERIENTIAL TEACHING DESIGN BASED ON KETANGPAI}

The idea of experiential teaching based on Ketangpai is shown in "Fig. 1": 


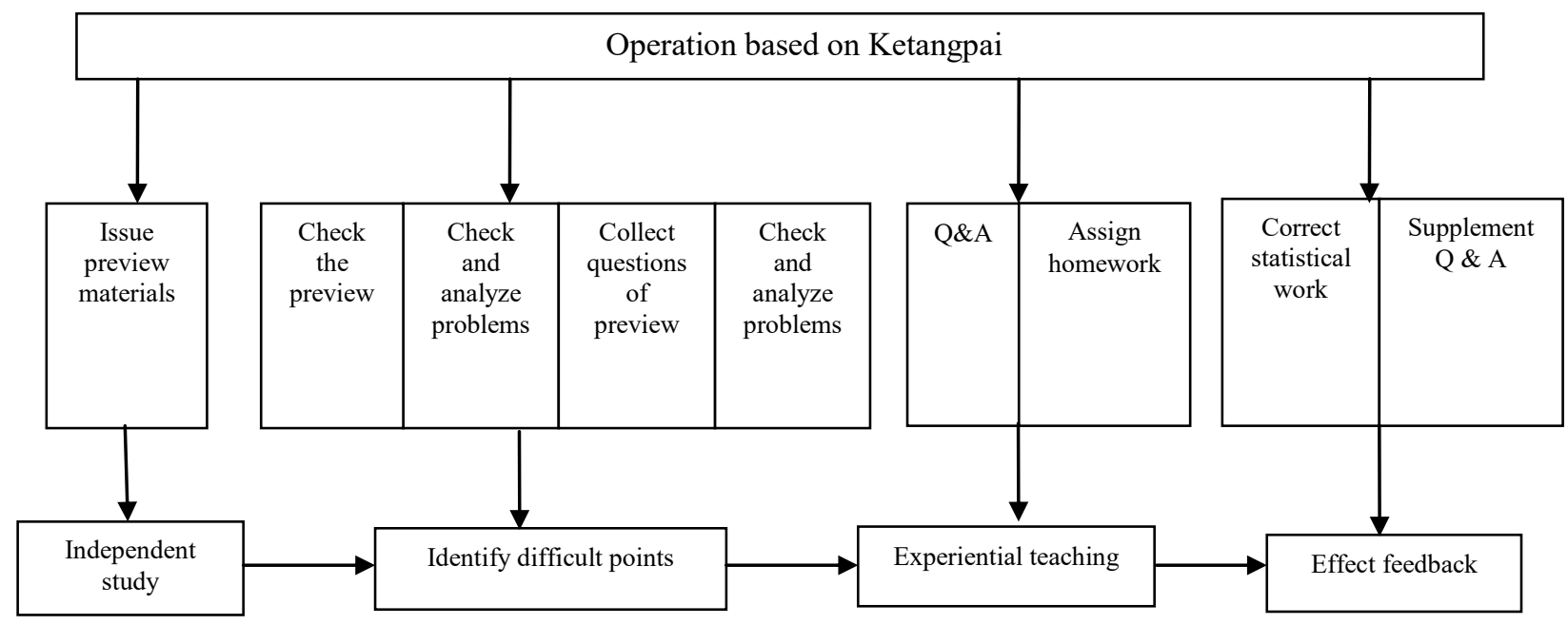

Fig. 1. Design ideas of experiential flipped classroom based on Ketangpai.

\section{TAKING "CHARACTERISTIC EXPLORATION" AS AN EXAMPLE TO SHOW THE SPECIFIC DESIGN CONTENT}

\section{A. Independent Study}

Two materials were distributed through Ketangpai before class: MBTI professional personality test (scale version: V2015-3.1) and MBTI video introduction (3 minutes). The back stage of Ketangpai can monitor whether the student has completed the preview task.

The forms of information include test and video, which are the learning material that students like. The enthusiasm of students is mobilized through the form of materials. In addition, students know that Ketangpai will monitor their preview situation, so they have motivation to learn.

\section{B. Identifying Problems}

1) Checking the preview situation: By using the analysis function of student's learning behavior in Ketangpai, it is possible to see which students have completed the learning tasks and which students have not completed the tasks, so that teachers can remind them to complete.

2) Collecting preview questions: They can distribute survey questions through Ketangpai: Which dimension of the test report is different from what you think?

A, E-I B, S-N C, T-F D, J-P. You can also ask students to leave a message for their questions.
3) Checking and analyzing problems: Through the students' answers to the survey questions and leaved questions, teachers can quickly classify the messy questions through the data analysis function of Ketangpai. According to the analysis results, the students' doubts are understood, and the lessons can be prepared in a targeted manner to improve the efficiency of preparing lessons.

\section{Experiential Teaching}

This experiential teaching first allows students to independently learn the learning materials distributed through Ketangpai. When learning the meaning of each dimension of MBTI, various interactive methods such as games are used to let students actively participate in the classroom, and personally understand the meaning of each dimension through these interactions to truly realize teaching with joy. After the students fully understand the meaning of each dimension, some games and other means are used to let them use the knowledge to identify the various dimensions of MBTI for others so as to truly realize "applying the knowledge". The specific process of this experiential teaching of independent study is shown in "Table I":

TABLE I. DESIGN OF Process OF EXPERIENTIAL TEACHING

\begin{tabular}{|c|l|}
\hline \multicolumn{2}{|c|}{ 1 organizing teaching (totally 2 minutes) } \\
\hline main task & sign in \\
\hline content & using QR code or password to sign in on the online classroom management platform Ketangpai \\
\hline $\begin{array}{c}\text { Teachers' } \\
\text { activity }\end{array}$ & $\begin{array}{l}\text { Log in to the PC terminal of Ketangpai to get the sign-in QR code or password and publish it; check-in data statistics } \\
\text { (visualized chart) }\end{array}$ \\
\hline $\begin{array}{c}\text { students' } \\
\text { activity }\end{array}$ & scan code by WeChat or enter password \\
\hline $\begin{array}{c}\text { Technical } \\
\text { resources }\end{array}$ & Online classroom management platform Ketangpai; WeChat \\
\hline
\end{tabular}




\begin{tabular}{|c|c|}
\hline \multicolumn{2}{|r|}{2 import new lessons and release classroom tasks (4 minutes in total) } \\
\hline main task & (1) pre-class display of MBTI personality type result and small interactive survey (about 3 minutes) \\
\hline content & $\begin{array}{l}\text { Show the MBTI test statistics made by the students before class. (visualized chart) } \\
\text { 2. Investigation questions: } \\
\text { Which dimension of the test report is different from what you think? } \\
\text { A, E-I B, S-N C, T-F D, J-P } \\
\text { 3. Display the statistics of small interactive survey (visualized chart) }\end{array}$ \\
\hline $\begin{array}{l}\text { Teachers' } \\
\text { activity }\end{array}$ & $\begin{array}{l}\text { 1. Call data from Ketangpai to show MBTI test results and interactive survey results; } 2 \text {. Make choices of teaching content } \\
\text { based on the students' doubts, and teach students according to their aptitude. (Selecting two dimensions from the four } \\
\text { dimensions of MBTI to teach by using experiential approach, but the teaching plan is prepared in four dimensions.) }\end{array}$ \\
\hline $\begin{array}{c}\text { students' } \\
\text { activity }\end{array}$ & Complete the small interactive survey on the platform Ketangpai. \\
\hline $\begin{array}{l}\text { Technical } \\
\text { resources }\end{array}$ & Online classroom management platform Ketangpai; WeChat \\
\hline main task & (2) Releasing classroom tasks (about 1 minute) \\
\hline content & $\begin{array}{l}\text { 1. Through the classroom games, examples and other ways, students can understand the meaning of each dimension and re- } \\
\text { evaluate themselves from the four dimensions of MBTI; (teacher quickly cover the two dimensions that haven'r been } \\
\text { explained specifically) } \\
\text { 2. When summarizing each dimension, each classmate helps the teacher analyze the personality traits according to the } \\
\text { teacher's narrative. The classmates who can analyze all of them accurately can get performance rewards of } 10 \text { ! }\end{array}$ \\
\hline $\begin{array}{l}\text { Teachers' } \\
\text { activity }\end{array}$ & present and release the task through PPT \\
\hline $\begin{array}{c}\text { students' } \\
\text { activity }\end{array}$ & accept the tasks \\
\hline \multicolumn{2}{|r|}{3 Relationship between personality and career (4 minutes) } \\
\hline main task & Understand their preferences and move the game experience to a relationship between personality and career \\
\hline content & $\begin{array}{l}\text { interactive game } \\
\text { write down their names with the right hand } \\
\text { change to use the left hand } \\
\text { 3. Discussion: What is the difference between the feelings of using two hands to write? } \\
\text { 4. let some students to share their feelings }\end{array}$ \\
\hline $\begin{array}{c}\text { Teachers' } \\
\text { activity }\end{array}$ & $\begin{array}{l}\text { Publish game tasks with PPT and explain the relationship between preferences and personality and career by interviewing } \\
\text { students. }\end{array}$ \\
\hline $\begin{array}{l}\text { students' } \\
\text { activity }\end{array}$ & Complete tasks and exchange feelings within the specified time \\
\hline \multicolumn{2}{|c|}{$\begin{array}{l}\text { 4, experiential teaching for the four dimensions of MBTI ( } 20 \text { minutes in total) } \\
\text { (Time allocation instructions: The highlighted two dimensions take } 16 \text { minutes, and the two dimensions explained in the example take } 4 \\
\text { minutes.) }\end{array}$} \\
\hline main task & (1) Identifying the dimension of energy tendency: $\mathrm{E}$ and I \\
\hline Content & $\begin{array}{l}\text { [interactive game] } \\
\text { Please review that how did you relax after the nervous college entrance examination? Each group writes down the summary } \\
\text { of the results of the discussion on a white paper. } \\
\text { Grouping method: The students with the pre-class test result of E are in one group and those with the result of I are in another } \\
\text { group. }\end{array}$ \\
\hline $\begin{array}{l}\text { Teachers' } \\
\text { activity }\end{array}$ & $\begin{array}{l}\text { 1. Release tasks and ask students to discuss in groups; } \\
\text { 2. Call the data from Ketangpai to display classmates list of } \mathrm{E} \text { and I group; (visualized chart) } \\
\text { 3. Inspect the class, listen to the students' discussion content, and observe the discussion atmosphere. } \\
\text { 4. Comment on the performance of each group of students. } \\
\text { 5. Summarize the dimension of energy tendency and help students internalize knowledge. }\end{array}$ \\
\hline $\begin{array}{l}\text { students' } \\
\text { activity }\end{array}$ & Participate in group discussions as required; and send representatives to report \\
\hline $\begin{array}{l}\text { Technical } \\
\text { resources }\end{array}$ & Online classroom management platform Ketangpai; WeChat \\
\hline main task & (2) Identifying the dimension of accepting information: $\mathrm{S}$ and $\mathrm{N}$ \\
\hline content & $\begin{array}{l}\text { Interactive activities] Empty mineral water bottle and a picture on the platform } \\
\text { All groups are invited to observe the mineral water bottle and the picture, and discuss the impression it gives them. Each } \\
\text { group summarizes, records in words, and sends the representative for reporting. } \\
\text { Grouping method: The students with the pre-class test result of S are in one group and those with the result of } \mathrm{N} \text { are in } \\
\text { another group. }\end{array}$ \\
\hline $\begin{array}{l}\text { Teachers' } \\
\text { activity }\end{array}$ & $\begin{array}{l}\text { 1. Release tasks and ask students to discuss in groups; } \\
\text { 2. Call the data from Ketangpai to display classmates list of } \mathrm{S} \text { and } \mathrm{N} \text { group; (visualized chart) } \\
\text { 3. Inspect the class, listen to the students' discussion content, and observe the discussion atmosphere. } \\
\text { 4. Comment on the performance of each group of students. } \\
\text { 5. Summarize the dimension of accepting information to help students internalize knowledge. }\end{array}$ \\
\hline $\begin{array}{c}\text { students' } \\
\text { activity }\end{array}$ & Participate in group discussions as required and send representatives to report \\
\hline $\begin{array}{l}\text { Technical } \\
\text { resources }\end{array}$ & Online classroom management platform Ketangpai; WeChat \\
\hline
\end{tabular}


4, experiential teaching for the four dimensions of MBTI (20 minutes in total)

(Time allocation instructions: The highlighted two dimensions take 16 minutes, and the two dimensions explained in the example take 4 minutes.)

\begin{tabular}{|c|c|}
\hline main task & (1) Identifying the dimension of processing information: $\mathrm{T}$ and $\mathrm{F}$ \\
\hline content & $\begin{array}{l}\text { [Case Analysis] How do you make decisions? } \\
\text { A military school stipulates that students who are found to have smoked three times will be ordered to drop out of school. If } \\
\text { you are the teacher charging the student's work at the military academy, one of the students was found to have smoked twice. } \\
\text { You talked about it with him seriously and warned him that if he is found for the third time he would be expelled. Now, this } \\
\text { student is found smoking for the third time when he is about to graduate. What will you do? Why? } \\
\text { Grouping method: The students with the pre-class test result of T are in one group and those with the result of F are in } \\
\text { another group. }\end{array}$ \\
\hline $\begin{array}{l}\text { teachers' } \\
\text { activities }\end{array}$ & $\begin{array}{l}\text { 1. Release tasks and ask students to discuss in groups; } \\
\text { 2. Call the data from Ketangpai to display classmates list of T and F group; (visualized chart) } \\
\text { 3. Inspect the class, listen to the students' discussion content, and observe the discussion atmosphere. } \\
\text { 4. Comment on the performance of each group of students. } \\
\text { 5. Summarize the dimensions of processing information to help students internalize knowledge. }\end{array}$ \\
\hline $\begin{array}{c}\text { students' } \\
\text { activity }\end{array}$ & Participate in group discussions as required and send representatives to report \\
\hline $\begin{array}{l}\text { Technical } \\
\text { resources }\end{array}$ & Online classroom management platform Ketangpai; WeChat \\
\hline main task & (1) Identifying the dimension of action pattern: $\mathrm{J}$ and $\mathrm{P}$ \\
\hline content & $\begin{array}{l}\text { activity planning } \\
\text { Your group plans to go to Fanyu Dafushan for barbecue tomorrow. Please write your plan on white paper. } \\
\text { Grouping method: The students with the pre-class test result of } \mathrm{J} \text { are in one group and those with the result of } \mathrm{P} \text { are in another } \\
\text { group. }\end{array}$ \\
\hline $\begin{array}{l}\text { teachers' } \\
\text { activity }\end{array}$ & $\begin{array}{l}\text { 1. Release tasks and ask students to discuss in groups; } \\
\text { 2. Call the data from Ketangpai to display classmates list of J and F group; (visualized chart) } \\
\text { 3. Inspect the class, listen to the students' discussion content, and observe the discussion atmosphere. } \\
\text { 4. Comment on the performance of each group of students. } \\
\text { 5. Summarize the dimensions of action pattern to help students internalize knowledge. }\end{array}$ \\
\hline $\begin{array}{c}\text { students' } \\
\text { activity }\end{array}$ & Participate in group discussions as required and send representatives to report \\
\hline $\begin{array}{l}\text { Technical } \\
\text { resources }\end{array}$ & Online classroom management platform Ketangpai; WeChat \\
\hline \multicolumn{2}{|r|}{5 sorting out the results of classroom tasks ( 5 minutes) } \\
\hline main task & Report the MBTI type of you and the teacher \\
\hline content & $\begin{array}{l}\text { [summary of Your MBTI type] } \\
\text { Type of self-selection } \\
\text { Type of occupational assessment } \\
\text { The type that best matches me } \\
\text { [The teacher's MBTI type in your mind] }\end{array}$ \\
\hline $\begin{array}{l}\text { teachers' } \\
\text { activity }\end{array}$ & $\begin{array}{l}\text { 1. Display statistical results (visualized chart) with Ketangpai; } \\
\text { 2. Randomly extract the students whose self-selection type in interview is inconsistent with the occupational assessment } \\
\text { result from the list in charts, and let them explain the adjustment reason to help them recognize their personality } \\
\text { characteristics; } \\
\text { 3. Add points to the students who have correctly judged the teacher's MBTI personality type. }\end{array}$ \\
\hline $\begin{array}{c}\text { students' } \\
\text { activity }\end{array}$ & Log in to the learning platform to fill in the results. If there is any adjustment, please explain the reason for the adjustment. \\
\hline $\begin{array}{l}\text { Technical } \\
\text { resources }\end{array}$ & Online classroom management platform Ketangpai; WeChat \\
\hline \multicolumn{2}{|r|}{6 visualized chart (totally 8 minutes) } \\
\hline content & $\begin{array}{l}\text { 1. How does the MBTI personality type match the job (about } 6 \text { minutes) } \\
\text { 2. Better understand the MBTI theory (about } 2 \text { minutes) }\end{array}$ \\
\hline $\begin{array}{c}\text { Teachers' } \\
\text { activity }\end{array}$ & $\begin{array}{l}\text { Get the statistical result of "type that matches me best" (visualization chart) from the database of Ketangpai; } \\
\text { Choose the personality type that is most common in class to explain career matching. }\end{array}$ \\
\hline $\begin{array}{c}\text { students' } \\
\text { activity }\end{array}$ & listen and experience \\
\hline $\begin{array}{l}\text { Technical } \\
\text { resources }\end{array}$ & Online classroom management platform Ketangpai; WeChat \\
\hline \multicolumn{2}{|r|}{7 teaching summary (about 1 minute) } \\
\hline \multicolumn{2}{|c|}{$\begin{array}{l}\text { Personality is one of the conditions for understanding professional development, but the character is neither good nor bad, because each } \\
\text { personality has its advantages. The best combination of personality and career will be more effective. } \\
\text { This lesson helps students to understand the relationship between personality and career, MBTI personality theory, the match between MBTI } \\
\text { personality type and occupation mainly through experiential teaching, with the hope that students accept their own personality characteristics, } \\
\text { consider personality factors when choosing a career, use MBTI personality theory to analyze themselves and others, and choose the right career. }\end{array}$} \\
\hline \multicolumn{2}{|c|}{8 assign homework and expansion (about 1 minute) } \\
\hline $\begin{array}{l}\text { Students log in } \\
\text { 1. Complete the } \\
\text { 2. Recommend }\end{array}$ & $\begin{array}{l}\text { tangpai to submit assignments: } \\
\text { of the character in "My Career Planning Archive" } \\
\text { ng — "Please understand me" "there is no need to use Mars to hit the Earth" }\end{array}$ \\
\hline
\end{tabular}




\section{Effect Feedback}

Through the homework system of Ketangpai, the students' homework can be automatically corrected, which greatly improves the teacher's homework correction speed, and it can feedback the teaching effect in time according to the completion of the homework, so that the teacher can continue to strengthen the difficult knowledge points in the future teaching. In addition, teachers can also supervise and remind students through the class to complete the homework, which helps to improve the completion rate.

\section{CONCLUSION}

This research mainly introduces the free information teaching platform Ketangpai and experiential teaching method into the flipped classroom teaching mode, and solves some of the resistances and problems encountered in implementing the flipped classroom teaching mode. In the follow-up study of the flipped classroom teaching mode, it is also possible to focus on the construction of self-made teaching resources, mobilize students to participate in the production of teaching materials, and make teaching resources close to the students, to enhance the attraction of flipped classroom.

\section{REFERENCES}

[1] Wang Yingmei. Research on the action of English flipped classroom in primary school under the concept of experiential teaching [D]. Shaanxi University of Technology, 2017. (in Chinese)

[2] Liu Shilan, Qian Lei, Yang Junzhong. The Influence of Project-based and Experiential Teaching on College Students' Immediate Combat Ability - Empirical Study Based on the Students in Guangzhou University City [J]. Education and Teaching Research 2018, (5), 2938. (in Chinese)

[3] Qing Qing. Design of pre-class task in flipped classroom based on ARCS model — Taking the course of "Business Etiquette and Communication" as an example [J]. Journal of Guilin Normal College, 2017, (11) 97-99. (in Chinese)

[4] Sun Yazhi. The Application of Online Classroom Management Tools in College Teaching - Taking Ketangpai as an Example[J]. Heilongjiang Science, 2017, (13) 42-43. (in Chinese)

[5] Ji Guoqiang. Exploration of high efficiency classroom informationization teaching mode based on Ketangpai. [J]. Vocational Technology, 2017, (1) 63-65. (in Chinese) 